\title{
Radioimmunoassay study of hepatic clearance and disappearance half-time of somatostatin and vasoactive intestinal peptide in dogs*
}

\author{
J A CHAYVIALLE, $\dagger$ P L RAYFORD, AND J C THOMPSON $\$$ \\ From the Department of Surgery, The University of Texas Medical Branch, Galveston, Texas, USA
}

SUMMARY The effects of hepatic transit on concentrations of synthetic cyclic (ovine) somatostatin and of highly purified (porcine) vasoactive intestinal peptide were studied in five conscious dogs prepared with indwelling portal catheters. The peptides were infused via peripheral vein catheters or the portal catheters for 40 minutes at actual integrated doses of $2.8 \mathrm{pmol} / \mathrm{kg} / \mathrm{min}$ for vasoactive intestinal peptide and $8 \cdot 2 \mathrm{pmol} / \mathrm{kg} / \mathrm{min}$ for somatostatin. Specific radioimmunoassays were used for the measurement of the circulating peptides. As estimated from the plateau peptide concentrations achieved in a hindleg vein during the portal and the peripheral infusions, the transhepatic loss of immunoreactive vasoactive intestinal peptide was $72.9 \pm 2 \cdot 1 \%$, against $27 \cdot 5 \pm 12 \cdot 5 \%$ for somatostatin. For the given doses of peptides infused systemically, the half-life, metabolic clearance rate, and distribution volume were, respectively, $1 \cdot 80 \pm 0 \cdot 1$ minutes, $39 \cdot 3 \pm$ $5 \cdot 2 \mathrm{ml} / \mathrm{kg} / \mathrm{min}$, and $103 \cdot 7 \pm 14.8 \mathrm{ml} / \mathrm{kg}$ for vasoactive intestinal peptide, and $1 \cdot 0 \pm 0.2$ minutes, $95 \cdot 2 \pm 12 \cdot 5 \mathrm{ml} / \mathrm{kg} / \mathrm{min}$, and $114 \cdot 7 \pm 6 \cdot 0 \mathrm{ml} / \mathrm{kg}$ for somatostatin. These results indicate that (ovine) somatostatin and (porcine) vasoactive intestinal peptide are both readily cleared from plasma in dogs. In the present experimental conditions, vasoactive intestinal peptide, but not somatostatin, was rapidly altered through hepatic transit so that it escaped recognition by the assay system.

Somatostatin, a tetradecapeptide first isolated from ovine hypothalamus, ${ }^{1}$ and vasoactive intestinal peptide (VIP), an octacosapeptide characterised from porcine upper intestine, ${ }^{2}$ are two of the peptides common to the central nervous system and the digestive tract. Both are widely distributed in the gastrointestinal tract and the pancreas, ${ }^{3}{ }^{4}$ and exogenous preparations exhibit wide spectra of biological effects. ${ }^{56}$ Physiological mechanisms of release and actions, however, are unclear for both.

The two peptides are considered local transmitters, either paracrine or neurocrine, although substances displaying somatostatin- and VIPimmunoreactivity have been detected in portal and

\footnotetext{
* This work was supported by grants from the National Institutes of Health (AM 15241) and the John A Hartford Foundation. Inc.

†Present address: Hopital Edouard-Herriot. Lyon. France.

$\$$ Address for correspondence: James $C$ Thompson. MD. Department of Surgery. The University of Texas Medical Branch. Galveston. Texas 77550. USA

Received for publication 17 March 1981
}

peripheral plasma. ${ }^{78}$ The physiological importance of these circulating components is not known.

The effect of hepatic transit on VIP originating from the digestive tract remains controversial. Physiological studies have shown that the biological activity of the peptide is reduced when it is infused into the portal vein instead of the peripheral circulation, ${ }^{910}$ but Strunz and colleagues ${ }^{11}$ failed to confirm this apparent hepatic inactivation. The hepatic inactivation of somatostatin has not been investigated.

The present work was undertaken to study comparatively the effects of hepatic transit on (ovine) somatostatin and (porcine) VIP in conscious dogs. Results derived from peripheral infusions were used to evaluate kinetics of uptake and distribution of the two peptides in this species.

\section{Methods}

Synthetic cyclic somatostatin (Serono Pharm Präp $\mathrm{GmbH}$, Freiburg/Breisgau, West Germany) and highly purified porcine VIP (a gift from Professor V 
Mutt, Karolinska Institutet, Stockholm) were dissolved in $0 \cdot 1 \mathrm{M}$ ammonium acetate $\mathrm{pH} 5 \cdot 5$ (somatostatin) and ().05 M hydrochloric acid $-0 \cdot 1 \mathrm{M}$ sodium chloride (VIP), and stored at $-80^{\circ} \mathrm{C}$. Before each experiment, an aliquot of the solution was diluted appropriately with $0 \cdot 15 \mathrm{M}$ sodium chloride and kept at $4^{\circ} \mathrm{C}$ until injected.

Five mongrel dogs $(20-28 \mathrm{~kg})$ that had been previously prepared with a Thomas gastric cannula, a Gregory cannula (positioned in the second part of the duodenum), and an indwelling portal catheter were used in the study. The silastic catheter in the portal lumen was inserted via a splenic tributary and was connected to a polyethylene catheter which was brought through the abdominal wall and pulled into the subcutaneous tissue of the back. Tests were not begun until 10 days after surgery. In no dog was there any sign of impaired gastric emptying. All portal catheters were patent for blood sampling at the time of the experiments, which were performed after an 18 hour fast without water restriction.

On the day of the test, the portal catheter was brought out through a small incision made under local anaesthesia and was connected to a no. 16 Intracath attached to a three-way stopcock. Another no. 16 Intracath was placed in a foreleg vein and connected to intravenous tubing identical with the one in the portal vein, so as to infuse the peptides via similar lines. Both lines were used for constant administration of isotonic saline or of the peptide solution, as appropriate, at a rate of $45 \mathrm{ml}$ per hour with an infusion pump (Harvard Apparatus Co, Inc, Millis, Mass). A no. 16 Intracath was placed in a hindleg vein for blood sampling and was kept patent with a slow saline infusion.

After 30 minutes of recovery and a 20 minute basal period, $10 \cdot 2 \mathrm{pmol} / \mathrm{kg} / \mathrm{min}$ somatostatin or $5 \cdot 0$ $\mathrm{pmol} / \mathrm{kg} / \mathrm{min}$ VIP was infused for 40 minutes via the portal or the peripheral line. The initial peptide and route of infusion were randomised. The second test, performed on the same day after one hour of recovery, used the other peptide infused via the other line. Two days later, each dog was given the peptides in the same order, but via the reverse routes of administration.

Blood from the hindleg catheter was collected in tubes with Trasylol $(800 \mathrm{U} / \mathrm{ml})$ and heparin $(8 \mathrm{U} / \mathrm{ml})$ every 10 minutes before the peptide infusion, at 10 , $20,30,35$, and 40 minutes during it, and at one, two, three, four, six, eight, 10,12,14 and 16 minutes after it. The fraction of somatostatin or VIP lost in the infusion line was estimated in a parallel experiment in which the two peptides, prepared along the same protocol as for in vivo studies, were perfused through five unused lines each. The aliquots of concentrated somatostatin and VIP used for these controls were taken from the same batch as those used for both the standard curves and the in vivo experiments. The effluent from each line was collected on ice during the 40 minute infusion, vortexed, and assayed immediately for the given peptide. The average figures then obtained were taken as the integrated doses actually delivered to the dogs, and were used for calculations. No attempt was made to study the adsorption kinetics of somatostatin and VIP on plastic tubing. With the present infusion sets, the integrated loss of peptide on tubing was $18.5 \% \pm 11.0 \%$ (SEM) for somatostatin and $44 \cdot 0 \% \pm 4 \cdot 4 \%$ for VIP.

Half-life, metabolic clearance rate (MCR), and distribution volume (DV) were estimated from the data of systemic infusion, using as incremental plateau value the mean incremental plasma peptide concentrations at 35 and 40 minutes during infusion. The half-life was calculated by the relation $T_{50}=$ $0 \cdot 693 / \mathrm{k}$, where $\mathrm{k}$ is the slope of the regression line between the natural logarithm of incremental plasma peptide concentration, expressed as percentage of plateau value, and time in minutes. The $M C R$, in $\mathrm{ml} / \mathrm{kg} / \mathrm{min}$, was equivalent to $\mathrm{D} / \mathrm{P}$, where $\mathrm{D}$ is the dose of peptide in $\mathrm{pmol} / \mathrm{kg} / \mathrm{min}$ and $\mathrm{P}$ the incremental peptide concentration at plateau value in $\mathrm{pmol} / \mathrm{ml}$. The $\mathrm{DV}$, in $\mathrm{ml} / \mathrm{kg}$, was equal to $\mathrm{D} / \mathrm{Pk}$.

The relation $\mathrm{Ps}-\mathrm{Pp} / \mathrm{Ps}$, where $\mathrm{Ps}$ and $\mathrm{Pp}$ are the mean incremental plasma peptide concentrations achieved during systemic (Ps) and portal (Pp) infusion, was used as an index of the fraction of peptide lost through a single hepatic transit.

The plasma somatostatin concentration was measured with a radioimmunoassay previously described, ${ }^{12}$ which was improved for determination of somatostatin in plasma by using antiserum 56D. ${ }^{13}$ This antiserum, raised against synthetic cyclic somatostatin conjugated with bovine albumin through carbodiimide condensation ${ }^{12}$ recognises primarily the 8-11 portion of the tetradecapeptide, as checked with analogues resulting from alanine substitution in positions $4,6,8$, and 11 (a gift from Dr J Rivier and Professor R Guillemin), which have relative potencies (ID 50) of $1 \cdot 0,0 \cdot 04,0 \cdot 008$ and $<0 \cdot 0004$, respectively, as compared with the unaltered molecule. 1-tyrosyl somatostatin (Serono) was labelled to a specific activity of 150 $220 \mu \mathrm{Ci} / \mu \mathrm{g}$ with ${ }^{125} \mathrm{I}$ (Amersham) using lactoperoxydase. It was purified by chromatography on a $1 \times 10 \mathrm{~cm}$ column of carboxymethylcellulose CM 52 , equilibrated and loaded in $0.05 \mathrm{M}$ ammonium acetate pH 5.5 and developed with $0.5 \mathrm{M}$ ammonium acetate $\mathrm{pH} 6 \cdot(0$. The sensitivity was $0 \cdot 9-1 \cdot 8$ $\mathrm{pmol} / \mathrm{l}$ of incubate. The within-assay (35 pairs) and between-assay (53 pairs) variations were $7 \cdot 1 \%$ and $12 \cdot 3 \%$, respectively (coefficient of variation). The 
recovery of $2,4,8$, and $16 \mathrm{pg}$ somatostatin per tube in plasma varied from $80.4 \%$ to $98.1 \%$ (seven determinations per dose).

VIP was measured with a radioimmunoassay recently reported ${ }^{13}$ using antiserum $76 \mathrm{~A}$, which shows only little reactivity towards the $\mathrm{C}$-terminal portion of the porcine peptide (ID 50:0.1) and no reactivity towards the $\mathrm{N}$-terminal part of the molecule $(<0.0001$, a gift from Professor M Bodanszky), as compared with the whole molecule $(=1 \cdot 0)$. Highly purified porcine VIP was labelled to a specific activity of $200-300 \mu \mathrm{Ci} / \mu \mathrm{g}$ with ${ }^{125} \mathrm{I}$ using lactoperoxidase, and was purified on a $1 \times 10$ column of SP C25 Sephadex equilibrated and loaded in $0 \cdot 2$ $\mathrm{M}$ ammonium acetate (pH 5.0) and developed with $0 \cdot 8 \mathrm{M}$ ammonium acetate ( $\mathrm{pH} 5.6$ ) with $5 \%$ human plasma. The sensitivity was $0.5-1.0 \mathrm{pmol} / \mathrm{l}$. The estimates for within-assay, between-assay variation, and recovery, tested as for somatostatin, were $7.0 \%, 7.2 \%$, and $79.7 \%$ to $100.4 \%$, respectively.

The two systems appeared to be specific against the other gastrointestinal peptides and brain peptides $^{12}$ tested at concentrations of $100 \mathrm{ng}$ per tube.

Both assay systems were used simultaneously to measure VIP and somatostatin in the same sample. A standard curve in charcoal-treated plasma was generated for each dog studied. Unknown samples and peptide-free plasma were acidified to $\mathrm{pH} 5 \cdot 5-6 \cdot 0$ with $0.4 \mathrm{M}$ acetic acid before incubation. Incubation lasted for five days at $4^{\circ} \mathrm{C}$ in $0.05 \mathrm{M}$ potassium phosphate- $0 \cdot 1 \mathrm{M}$ sodium chloride $\mathrm{pH} 5 \cdot 5$, with addition of tracer after 24 hours and of second antibody (used for separation of bound and free peptide) added on the fourth day. Results were expressed as $\mathrm{pmol} / \mathrm{l}$ and converted into $\mathrm{pmol} / \mathrm{ml}$ for calculations. The sensitivity limit of the individual assay was taken as the actual value for samples with concentrations below the limits of detection.

\section{Results}

Systemic infusion of VIP at $5 \cdot 0 \mathrm{pmol} / \mathrm{kg} / \mathrm{min}$ (actual value as measured: $2.8 \mathrm{pmol} / \mathrm{kg} / \mathrm{min}$ ) induced an increase in peripheral plasma VIP from $4 \cdot 0 \pm 0 \cdot 8$ $\mathrm{pmol} / \mathrm{l}$ to a mean plateau value of $81 \cdot 0 \pm 10 \cdot 1 \mathrm{pmol} / \mathrm{l}$. An increase from $4 \cdot 5 \pm 0 \cdot 8$ to $25 \cdot 6 \pm 3 \cdot 4 \mathrm{pmol} / \mathrm{l}$ was found when the same dose was delivered into the portal vein (Fig. 1). The estimated loss of peptide on hepatic transit was $72 \cdot 9 \pm 2 \cdot 1 \%$. After the infusion was stopped, the plasma VIP concentration decreased to baseline in 14 minutes after systemic administration, and in eight minutes after portal infusion. Estimated from the results of systemic infusion, the half-life (Fig. 2), metabolic clearance rate, and apparent volume of distribution of porcine

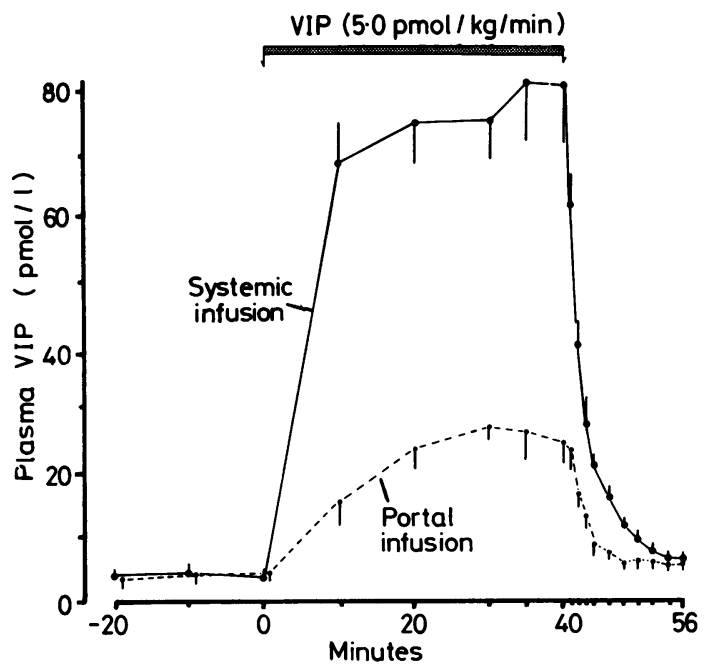

Fig. 1 Mean $\pm S E$ peripheral plasma VIP concentration in five conscious dogs given 5.0 pimol $/ \mathrm{kg} / \mathrm{min}$ (actual dose $2 \cdot 8$ pmol $/ \mathrm{kg} / \mathrm{min}$ ) highly purified porcine VIP intraportally or systemically.

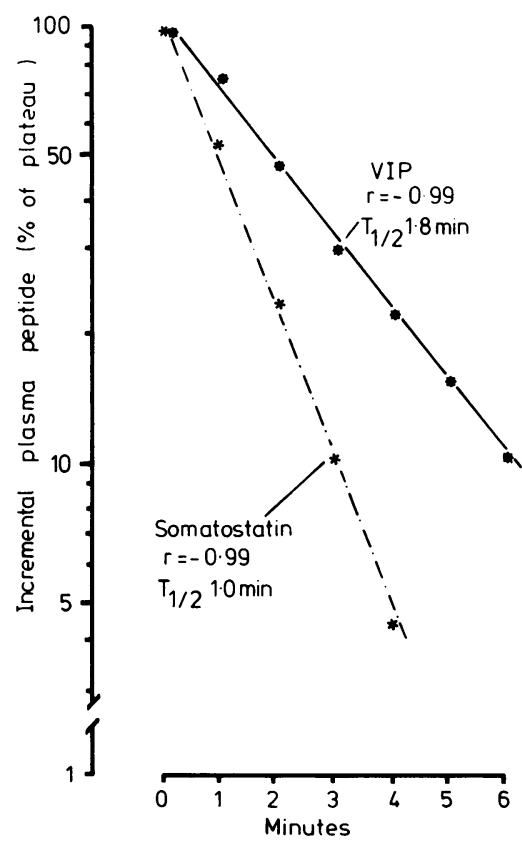

Fig. 2 Regression lines of incremental VIP and somatostatin concentrations in peripheral plasma (expressed as percentage of plateau value) with time after stopping an infusion of actual $2.8 \mathrm{pmol} / \mathrm{kg} / \mathrm{min}$ VIP or 8.2 $\mathrm{pmol} / \mathrm{kg} / \mathrm{min}$ somatostatin delivered during 40 minutes. Mean incremental plateau value taken as $100 \%$ at end of infusion (zero time). 
VIP were calculated to be $1 \cdot 80 \pm 0 \cdot 1$ minutes, $39 \cdot 3 \pm$ $5 \cdot 2 \mathrm{ml} / \mathrm{kg} / \mathrm{min}$, and $103.7 \pm 14 \cdot 8 \mathrm{ml} / \mathrm{kg}$, respectively.

Systemic infusion of $10.2 \mathrm{pmol} / \mathrm{kg} / \mathrm{min}$ (actual dose as measured: $8 \cdot 2 \mathrm{pmol} / \mathrm{kg} / \mathrm{min}$ ) somatostatin caused plasma somatostatin to increase from $15 \cdot 2 \pm$ $6 \cdot 8$ to a mean plateau value of $108 \cdot 6 \pm 14 \cdot 0 \mathrm{pmol} / \mathrm{l}$, as compared with an increase with portal infusion from $18 \cdot 4 \pm 6 \cdot 5$ at basal to $83 \cdot 8 \pm 16 \cdot 8 \mathrm{pmol} / \mathrm{l}$ (Fig. 3 ). The apparent loss of somatostatin on hepatic transit was $27 \cdot 5 \pm 12 \cdot 5 \%$. At the end of the infusion, the curves of plasma somatostatin after portal and systemic infusions were superimposable, and the mean values for both returned to baseline in four minutes (Fig. 3). Estimated from the data of systemic infusion, the half-life (Fig. 2) was calculated by extrapolation to be $1 \cdot 0 \pm 0 \cdot 2$ minutes. The metabolic clearance rate was $95.2 \pm 12.5 \mathrm{ml} / \mathrm{kg} / \mathrm{min}$ and the apparent volume of distribution, $114 \cdot 7 \pm 6 \cdot 0 \mathrm{ml} / \mathrm{kg}$.

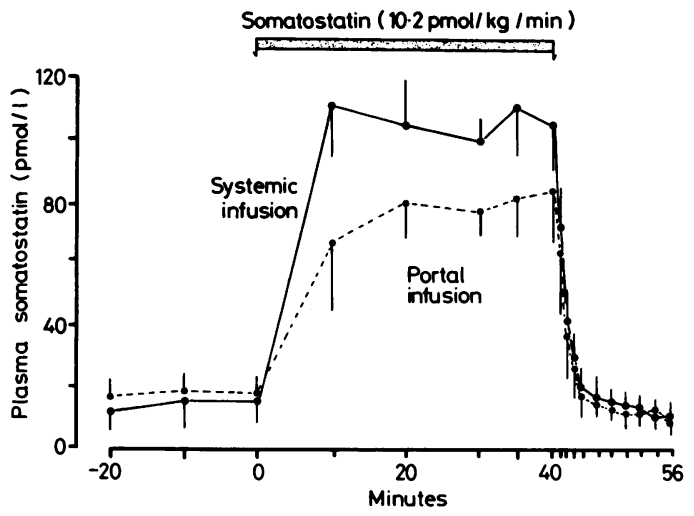

Fig. 3 Mean $\pm S E$ peripheral plasma somatostatin concentrations in five conscious dogs given $10 \cdot 2$ pmol $/ \mathrm{kg} /$ min (actual dose $8.2 \mathrm{pmol} / \mathrm{kg} / \mathrm{min}$ ) synthetic cyclic somatostatin intraportally or systemically.

\section{Discussion}

The present study was undertaken to evaluate comparatively the effects of hepatic transit on ovine somatostatin and porcine VIP administered to conscious dogs at single doses known to induce significant biological effects. Ovine somatostatin delivered intravenously at a theoretical rate of $1 \mu \mathrm{g} / \mathrm{kg} / \mathrm{h}(10 \cdot 2 \mathrm{pmol} / \mathrm{kg} / \mathrm{min})$ has been shown to inhibit the postprandial release of gastrin and acid response in man, ${ }^{14}$ as well as the release of insulin and glucagon in dogs. ${ }^{15}$ Porcine VIP, delivered at the theoretical dose of $1 \mu \mathrm{g} / \mathrm{kg} / \mathrm{h}(5 \cdot 0 \mathrm{pmol} / \mathrm{kg} / \mathrm{min})$, significantly inhibited the meal-induced acid response and release of gastrin in dogs. ${ }^{16}$ As the adsorption of secretin, which is structurally related to VIP, on plastic tubing, amounts to nearly $50 \%$ of doses which were similar to those used here for VIP and somatostatin, ${ }^{17}$ the adsorption of these preparations on the infusion sets was checked in parallel control experiments. Somatostatin was only slightly adsorbed, while the integrated loss of VIP during a 40 minute infusion almost reached $50 \%$ of the initial dose, a figure rather similar to that reported in the single study in which this estimation was reported. ${ }^{18}$ We did not attempt to delineate the adsorption kinetics of somatostatin and VIP on plastic tubing, because the infusion lines were strictly replicated for the portal and the peripheral infusions. However, the fact that the values of plasma somatostatin and of plasma VIP at 35 and 40 minutes under peripheral or portal infusion did not vary from the corresponding 20 and 30 minute estimates by more than $10 \%$, does suggest that the delivery of each peptide was fairly constant during the second 20 minute period.

Somatostatin was apparently affected only moderately by hepatic transit (uptake or alteration of $27.5 \pm 12.5 \%$ of peptide infused through the portal system). Whether the fraction of peptide resisting hepatic transit was biologically active was not tested in the present study. However, antiserum $56 \mathrm{D}$ recognises a portion of the tetradecapeptide which appears to be essential for biological activity, especially the phenylalanine residue in position $8 .{ }^{19}$ Our data do not exclude a transhepatic alteration of the $\mathrm{N}$-terminal portion of the tetradecapeptide, but provide circumstantial evidence for possible effects of the somatostatin originating from the digestive system on post-hepatic target organs.

From the present results, it appears that somatostatin (at least the ovine tetradecapeptide) is readily cleared from plasma in dogs, with a half-life of approximately one minute. This figure is roughly comparable with that $(1.82$ minutes) derived from studies in dogs by Schusdziarra and colleagues. ${ }^{15}$ These authors recorded an increase of plasma somatostatin of about $300 \%$ above basal for an apparent dose of approximately $10 \cdot 0-12 \cdot 0 \mathrm{pmol} / \mathrm{kg} / \mathrm{min}$, as compared with the $600 \%$ increase obtained with $10 \cdot 2 \mathrm{pmol} / \mathrm{kg} / \mathrm{min}$ in the present study. The discrepancy appears to result from different estimates for basal plasma somatostatin concentrations in dogs, probably because of different antiserum specificities or assay methodologies. Half-life values of $1 \cdot 1-3 \cdot 0$ minutes were recently reported in man, ${ }^{20}$ with MCR values of $15-45 \mathrm{ml} / \mathrm{kg} / \mathrm{min}$. The figure obtained here and that given by Schusdziarra and colleagues ${ }^{15}$ in dogs suggest that somatostatin may be cleared more rapidly from plasma in dogs than in man. 
In experimental conditions identical with those applied for somatostatin, the half-life of porcine VIP was close to two minutes. This figure is intermediate between those reported by Domschke and colleagues $^{18}$ in man and by Modlin and colleagues ${ }^{21}$ in anaesthetised pigs, both close to one minute, and that (about three minutes) reported by Strunz and colleagues $^{11}$ in dogs with portacaval transposition. As to other aspects of VIP kinetics, the present figures are different from those obtained by Modlin and colleagues ${ }^{21}$ and Domschke and colleagues. ${ }^{18}$ Using the same VIP assay for the two studies, these groups recorded a distribution volume of VIP of less than $2 \%$ of the body weight both in man and pigs, as compared with a figure of about $10 \%$ in the present experiment. As the doses of peptides actually infused were controlled in all these studies, and as at least some of these doses were comparable, the most likely reason for this discrepancy is the difference between the plasma VIP levels achieved under infusion, which were lower in our study than in theirs. The same batch of pure VIP was used here for the in vivo infusions, and in vitro adsorption controls, and for setting up the standard curves, so that it is unlikely that the comparatively low plasma VIP levels achieved here reflected simply the administration of a spuriously low amount of peptide. Though the metabolism of porcine VIP may be different in dogs and in other species, as suggested by the fact that the half-life in $\operatorname{dog} \mathrm{s}^{11}$ was found to be three times as high as those in $\operatorname{man}^{18}$ and in pigs $^{21}$ in the same assay system, an additional explanation may be that different components with VIP immunoreactivity, circulating in plasma during a prolonged infusion of the peptide, are recognised to different extents by the various antisera. This hypothesis would require collaborative studies investigating the molecular patterns of the immunoreactive components detected in the different systems.

From studies performed in conscious dogs with portacaval transposition, Strunz et al. ${ }^{11}$ reported that neither the biological activity nor the immunoreactivity of porcine VIP was affected by hepatic transit. These results were clearly at variance with previous evidence of biological inactivation of VIP in anaesthetised dogs ${ }^{9}$ and cats ${ }^{10}$ and immunological alteration of the peptide in anaesthetised pigs. ${ }^{21}$ As anaesthesia may well have interfered with the hepatic metabolism of VIP, the present study was undertaken to compare the fate of VIP with that of somatostatin in conscious dogs. The results clearly support previous evidence for rapid alteration of VIP on single hepatic transit in dogs. As the present VIP assay recognises only slightly the C-terminal portion and not at all the $\mathrm{N}$-terminal portion of the molecule, the sharp difference between the plateau levels achieved under portal versus peripheral infusion may have resulted either from complete uptake of the molecule or, alternatively, from its cleavage into fragments poorly recognised by our antiserum. Both alternatives, however, appear likely to result in reduction of biological potency of the same order as that depicted by Kitamura and colleagues $^{9}$ and of Konturek and colleagues. ${ }^{10} 2223$

Somatostatin and VIP are two of the peptides shared by the nervous system and the digestive tract. The physiological status of each peptide remains to be elucidated, though the current line of evidence favours somatostatin as a paracrine substance and VIP as a neurotransmitter. Although they were obtained after infusing single test doses of non-canine sequences, the present results suggest that a possible physiological role of digestive somatostatin beyond the liver should not be overlooked, while the rapid hepatic clearance of immunoreactive porcine VIP, along with the presence of VIP receptors on the hepatocytes ${ }^{24}$ and the fact that the exogenous peptide induces glycogenolysis, ${ }^{25}$ suggests a possible gut-liver axis for the peptide released from gastrointestinal stores.

\section{References}

'Brazeau P, Vale W, Burgus R, et al. Hypothalamic peptide that inhibits the secretion of immunoreactive pituitary growth hormone. Science 1973; 179: 77-9.

${ }^{2}$ Said SI, Mutt V. Isolation from porcine intestinal wall of a vasoactive octacosapeptide related to secretin and to glucagon. Eur J Biochem 1972; 28: 199-204.

${ }^{3}$ Bryant MG, Bloom SR, Polak JM, Albuquerque RH, Modlin I, Pearse AGE. Possible dual role for vasoactive intestinal peptide as gastrointestinal hormone and neurotransmitter substance. Lancet 1976; 1: 991-3.

${ }^{4}$ Alumets J, Sundler F, Håkanson R. Distribution, ontogeny, and ultrastructure of somatostatin immunoreactive cells in the pancreas and gut. Cell Tiss Res 1977; 185: 465-79.

"Makhlouf GM, Said SI. The effect of vasoactive intestinal peptide (VIP) on digestive and hormonal function. In: Thompson JC, ed. Gastrointestinal hormones. Austin: University of Texas Press, 1975: 599-610.

${ }^{6}$ Gerich JE, Patton GS. Somatostatin: physiology and clinical applications. Med Clin N Am 1978; 62: 375-9.1. 'Bloom SR, Polak JM. The role of VIP in pancreatic cholera. In: Thompson JC, ed. Gastrointestinal hormones. Austin: University of Texas Press, 1975: $635-42$.

${ }^{8}$ Schusdziarra V, Harris V, Conlon JM, Arimura A, Unger R. Pancreatic and gastric somatostatin release in response to intragastric and intraduodenal nutrients and $\mathrm{HCl}$ in the dog. J Clin Invest 1978; 62: 509-18.

${ }^{9}$ Kitamura S, Yoshida T, Said I. Vasoactive intestinal polypeptide: Inactivation in liver and potentiation in 
lung of anesthetized dogs. Proc Soc Exp Biol Med 1975; 148: $25-9$.

${ }^{10}$ Konturek SJ, Domschke S, Domschke W, Wunsch E, Demling L. Comparison of pancreatic responses to portal and systemic secretin and VIP in cats. Am J Physiol 1977; 232: E156-8.

${ }^{11}$ Strunz UT, Walsh JH, Bloom SR, Thompson MR, Grossman MI. Lack of hepatic inactivation of canine vasoactive intestinal peptide. Gastroenterology 1977; 73: 768-71.

${ }^{12}$ Chayvialle JA, Descos F, Bernard C, Martin A, Barbe C, Partensky C. Somatostatin in mucosa of stomach and duodenum in gastroduodenal disease. Gastroenterology 1978; 75: 13-19.

${ }^{13}$ Guzman S, Chayvialle JA, Banks W, Rayford PL, Thompson JC. Effect of vagal stimulation on pancreatic secretion and on blood levels of gastrin, cholecystokinin, secretin, vasoactive intestinal peptide and somatostatin. Surgery 1979; 86: 329-36.

${ }^{14}$ Barros D'Sa AAJ, Bloom SR, Baron JH. Inhibition by somatostatin (growth-hormone release-inhibiting hormone, GH-RIH) of gastric acid and pepsin and G-cell release of gastrin. Gut 1978; 19: 315-20.

${ }^{15}$ Schusdziarra V, Harris V, Unger RH. Half-life of somatostatin-like immunoreactivity in canine plasma. Endocrinology 1979; 104: 109-10.

${ }^{16}$ Villar HV, Fender HR, Rayford PL, Bloom SR, Ramus NI, Thompson JC. Suppression of gastrin release and gastric secretion by gastric inhibitory peptide (GIP) and vasoactive intestinal polypeptide (VIP). Ann Surg 1976; 184: $97-102$.

${ }^{17}$ Miyata M, Rayford PL, Thompson JC. Loss of secretin from plastic infusion systems. (Letter). $N$ Engl J Med 1979; 301: 1066

${ }^{18}$ Domschke S, Domschke W, Bloom SR, et al. VIP in man: pharmacokinetics, metabolic and circulatory effects. Gut 1978: 19: 1049-53.

${ }^{19}$ Brown MP. Coy DH, Gomez Pan A, et al. Structureactivity relationships of eighteen somatostatin analogues on gastric secretion. J Physiol (Lond) 1978; 277: 1-14.

${ }^{20}$ Sheppard M, Shapiro B. Pimstone B, Kronheim S, Berelowitz M, Gregory M. Metabolic clearance and plasma half-disappearance time of exogenous somatostatin in man. J Clin Endocrinol Metab 1979; 48: 50-3.

${ }^{21}$ Modlin IM, Mitchell SJ, Bloom SR. The systemic release and pharmacokinetics of VIP. In: Bloom SR, ed. Gut hormones. Edinburgh: Churchill Livingstone, 1978: 470-4.

${ }^{22}$ Bodansky M, Henes JB, Yiotakis AE, Said SI. Synthesis and pharmacological properties of the N-terminal decapeptide of the vasoactive intestinal peptide (VIP). $J$ Med Chem 1977; 20: 1461-4.

${ }^{23}$ Makhlouf GM, Zfass AM, Said SI, Schebalin M. Effects of synthetic vasoactive intestinal peptide (VIP), secretin and their partial sequences on gastric secretion. Proc Soc Exp Biol Med 1978; 157: 565-8.

${ }^{24}$ Bataille D, Freychet $P$, Rosselin G. Interactions of glucagon, gut glucagon, vasoactive intestinal polypeptide and secretin with liver and fat cell plasma membranes: Binding to specific sites and stimulation of adenylate cyclase. Endocrinology 1974; 95: 713-21.

${ }^{25}$ Kerins C, Said SI. Hyperglycemic and glycogenolytic effects of vasoactive intestinal polypeptide. Proc Soc Exp Biol Med 1973; 142: 1014-7. 